\title{
Public Spending and Economic Growth in Developing Countries: a Synthesis
}

\author{
Kouakou Bérenger Kouassi \\ Research Officer and Consultant at Paddel Afrique, France.
}

\begin{abstract}
The purpose of this study is to critically analyze the theorical and empirical literature on the relationship between public expenditures and economic growth. This relationship has been source of controversy with liberal economists, Keynesians and proponents of endogenous growth. Liberal theories promoted self-regulating markets mechanisms. But these theories have also revealed the conditions of state intervention in the economy. According to Keynes, unemployment is not only linked to labor market. It is linked to other markets and especially to finance. Keynes advocated state intervention via public expenditure. That intervention should take two dominant forms, namely the economic policies in favor of investment and income redistribution policies. Robert Barro showed the contribution of public spending to economic growth, with particular emphasis on public infrastructures. He argued that government spending on infrastructure investment improves private companies' productivity. Thus, it causes increasing return to scale, in the long run. He recommended therefore its funding through taxation. The theories listed above focused on the necessity of state intervention in the economy. They addressed indirectly the impact of public spending on economic growth. Nevertheless, it should be stressed that the evolution of public spending may depend on economic growth. Adolph Wagner showed that public expenditures increase more than proportionally in relation to economic growth. Numerous empirical studies tested the relationship between the two variables in developing countries. These studies involved the level of public spending and its composition. In both cases, the results are controversial. A number of studies confirmed Wagner' law; other studies validated the Keynesian assumption. Other studies rejected both Wagner's law and Keynesian assumption.
\end{abstract}

Keys words: National Government Expenditure, Public Economics, Public Expenditure, Public Finance, economic growth, Developing countries.

JEL Classification: H50, H54, O10, O4.

(C) The Authors, 2018. This article is published with open access at Sumy State University.

\section{Introduction}

Fiscal policy is a key element of economic policy of developing countries and regions. This policy is a vehicle to promote economic growth and development. In fact, fiscal policy is frequently used to affect the level of economic activity and the quality of life of populations. Therefore, it is extremely important to study and understand the relationship between fiscal policy and economic growth in developing countries and regions. To better understand this relationship, we must reiterate the definition of some basic concepts. Public expenditures refer to the expenditures of central or federal state, local authorities, public-sector administrative establishments, social security institutions (dictionary encyclopedia of public finance, 1991). The growth of national economy is a quantitative notion that refers to the long-run growth of national production. That growth is endogenous if the process of growth is self-sustained.

For several decades, theoretical and empirical economic studies paid particular attention to the relationship between public spending and economic growth, in particular Keynes (1936), Wagner (1872), Barro (1990), Nubukpo(2007), Ouattara (2007), Govindaraju et al (2011), Akitoby et al. (2006), Togbenu (2017), Bose et al. (2007), Gupta et al. (2005) .However, only a few studies focused on the review of literature on the relationship between public expenditures and economic growth.

The purpose of this study is to critically analyze the theoretical and empirical literature on the relationship between public expenditures and economic growth. It is divided into two main parts. The first one is focused on the theoretical debate of state intervention in the economy. The second one deals with the empirical contributions in developing countries.

\section{Litterature}

\section{State intervention in the economy: a few theoretical contributions}

\section{From liberal theories to keynesian revolution}

State intervention in the economy has been the subject of long debates among economists. Some highlighted 
self-regulating mechanisms of markets, some reported a lack of faith in these mechanisms, and advocated for the state intervention in the economy.

a. The self-regulating market : from Adam Smith to Leon Walras and F. Hayek. For Adam Smith, in a competitive economy, individual egïstic behaviours, lead to the satisfaction of general interests. For him, that mechanism was due to the existence of an invisible hand. He said that the competitive market is the prerequisite to use productive resources in an optimal way. Adam Smith's analysis can be summarized in explaining market regulation by price mechanisms. That means how price adjustment determines market equilibrium. Smith was strongly opposed to price determination and said that variation insures the balance between supply and demand. According to Smith, prices insure the regulation of market economy. And thus, the state intervention could interfere with price adjustment. Therefore, State should avoid intervening in the economy. Generally speaking, classical and neoclassical economists postulate that the pursuit of individual interests leads to general equilibrium, in a situation of competitive equilibrium. Neoclassical theory is an extension of classical economist's theories. Neoclassical economists support the idea that the market allows a stable balance to be achieved. But the interpretation of this concept varies from author to author. Leon Walras examined the conditions of perfect competition. He also showed that these conditions lead to the achievement of general equilibrium. His General Equilibrium Theory is an application of the supply/ demand balance for a good to a national economy. He contributed to defining a precise optimal situation of an economy based upon perfect competition assumptions. Pareto deepened that idea showing that this equilibrium as an optimum. For him, this balance is right. Any attempt to change the balance could increase the satisfaction of an economic agent and reduce the satisfaction of another agent. The Austrian school of economics has been very hostile to state intervention in the economy. The authors take the view that the market alone can make compatible the actions of individuals without imposing serious constraints on liberties. However, Hayek, a representative of that school, questioned the classical and neoclassical assumption. For him, market may not lead to the equilibrium. $\mathrm{He}$ also highlighted the limitations of Keynesian theory of State intervention in the economy. In fact, he said that state intervention is a hindrance to economic and political liberties of individuals. He also said that state intervention causes disturbance to spontaneous order, what he described as the best form of economic organization. Hayek, representative of the Austrian school, questioned the classical and neoclassical assumption. For him, market just makes compatible individual decisions, and safeguards economic agents' freedom. It may not lead to equilibrium. Nevertheless, Hayek showed the limitation of Keynesian government intervention. He said, indeed, that, the latter is a major hindrance economical and political freedom of economic agents. For him, state intervention causes disturbance to spontaneous order. He considers this latter as the best form of economic organization. Hayek (1931) has stressed that state intervention in the economy may cause the allocation of capital and labor factors to be ineffective. In other words, state intervention may lead up production factors to pointless productions. Hayek (1944) mentioned that state intervention conflicts with personal interests and economic freedom. It has therefore been identified has planning; that is a central direction for the whole economic activity. This single plan shows how resources should be used and for what purposes.

b. Liberal justifications of state intervention in the economy. It both concerns classical and neoclassical schools. In fact, classical economists found out that competition often leads to a monopoly. This applies to activities where average production costs decreases with quantities produced. That particular situation requires state intervention. Adam Smith still advocated for the state intervention in some sectors of the economy. He suggested states to create some infrastructures and help education of the poorest children. Neoclassical school also justified State intervention in the economy. Pigou and Samuelson demonstrated that competition do not always coincide with effectiveness. For them, market may be failing, and in the latter case, the intervention of the state is necessary.

c. Keynesian revolution. Pre-Keynesian economic analysis has dealt with the question of optimal allocation of resources and price fixing in the long run. But, the main focus of interest of Keynes was the analysis of production and employment determinants, in the short run .The primary objective of Keynesian theory was to examine the causes of underemployment, which is in the form of involuntary unemployment. Keynes questioned the notion of full-employment, claiming that the latter is unstable and temporary. For Keynes, the achievement of full-employment equilibrium is not automatic. State must intervene in the economy to come closest to full-employment. He showed that labor market equilibrium may coincide with the existence of underemployment. He defined the underemployment equilibrium as a situation where equilibrating aggregate demand and supply do not require available labor force utilization. In other words, driving down salaries is not a sufficient condition for addressing unemployment issues. Keynes analysis did not deal with a single 
market. It has taken account of the interdependence of all markets. Thus, unemployment is not only linked to labor market. It is linked to other markets and especially to finance. Keynes advocated state intervention via public expenditure. That intervention should take two dominant forms, namely the economic policies in favor of investment and income redistribution policies.

\section{Contribution of endogenous economic growth theory: Barro model.}

The theory is based upon a criticism of neoclassical model of growth. Proponents of endogenous growth sought out the causes of increasing returns to scale; In other words, factors contributing to the most important variance of production in relation to changes in production factors. According to these theories, four factors influence economic growth. Among them, Barro (1990) showed the contribution of public spending to economic growth, with particular emphasis on public infrastructures. He argued that government spending on infrastructure investment improves private companies' productivity. Thus, it causes increasing return to scale, in the long run. Barro (1990) recommended therefore their funding through taxation.

The theories listed above focused on the necessity of state intervention in the economy. They addressed indirectly the impact of public spending on economic growth. Nevertheless, it should be stressed that the evolution of public spending may depend on economic growth. Adolph Wagner showed that public expenditures increase more than proportionally in relation to economic growth.

\section{Public Spending and Economic Growth in Developing Countries: Empirical Contributions}

A number of studies focused on the relationship between public spending and economic growth in developing countries.

\section{Public spending level and economic growth in developing countries.}

Some of these empirical studies focused on the relationship between government expenditures level and economic growth. In fact, Okoro (2013) analyzed the impact of government expenditure on economic growth in Nigeria from 1980 to 2011. The results highlighted the existence of a long run relationship between public expenditures and economic growth. Segun and Adelowokan (2015) examined the impact of public spending on economic growth in Nigeria from 1970 to 2008. The empirical results of this study showed that public spending have a positive and significant impact on economic growth. But, Dikeogu et al. (2016) analyzed the impact of aggregate public spending on economic growth in Nigeria from 1970 to 2013.For their part, Oni and Ozemhoka (2014) assessed the impact of public expenditures one economic growth from 1981 to 2011. Results from this study indicate that there is a positive relationship between public expenditures and economic growth. Gangal and Gupta (2013) also analyzed the impact of public spending on economic growth in India from 1998 to 2012. Their results revealed the existence of a long run relationship between the two variables. The results also indicated that total public spending have a positive impact on economic growth. They also found that total public expenditures cause (in the sense of Granger) GDP. Srinivasan (2013) investigated the causal relationship between public spending and economic growth in India from 1973 to 2012. The results confirmed the existence of a long run relationship between public expenditures and economic growth. He also found one-sense causality from growth to public expenditures, both in the short term and in the long term, thus confirming Wagner's law. Ahmad (2014) tested the validity of Wagner`s law in India from 1980 to 2013. Unlike Gangal and Gupta (2013), this study revealed a one-way causality from GDP per capita to public spending, which confirmed Wagner`s law. Jaroensathapornku (2010) examined the causal relationship between public spending and economic growth in Thailand from 1993 to 2006, using Granger causality test. He found no cointegration relationship between public spending and economic growth. The results also showed that public spending causes economic growth. However, economic growth was not found to cause public expenditures. Ordinary least squares results showed that government expenditures positively influence eonomic growth. Bagdigen and Cetintas (2009) examined the long run relationship between government expenditures and economic growth in Turkey from 1965 to 2000. They reported that there is no causal relationship between Gross Domestic Product and public expenditures. Korkmaz (2013) tested the impact of public expenditures on economic growth in Turkey. He found that public expenditures do not influence economic growth, but economic growth positively affects public expenditures. Unlike Bagdigen and Cetintas (2009), this result confirmed Wagner's law. Yilgör et al. (2012) also analysed the relationship between public spending and economic growth in Turkey. Their study reported that total public expenditures cause economic growth. This result is thus very different from that of Bagdigen and Cetintas (2009) and that of Korkmaz (2013). Nubukpo (2003) examined the impact of public spending level on economic growth of West African 
Economic and Monetary Union countries. That study findings indicate that, in the short run, total public spending has no significant impact on growth for the majority of that union countries; but in the long run, he founded an impact on growth that varies for each country. Furthermore, Ouattara (2007) tested the causal relationship between public spending and economic growth for the same countries. The results highlighted a long run relationship between public spending, corruption and economic growth. Yasin (2003) examined the impact of public spending on economic growth for a sample of 26 countries of Sub-Saharan Africa from 1986 to 1997 . He found that total public expenditures have significant positive impact on economic growth. Govindaraju et al (2011) studied the impact of aggregate spending on economic growth for a group of developing countries from 1970 to 2006. That study has been realized in two different frameworks. In univariate framework, the results of that study verified Wagner's law; While, in a multivariate case, the study supported Keynesian theory. For their part, Bayraktar and Moreno-Dodson (2015) look for the change in impact of public spending on growth for a sample of developing countries, from 1970 to 2005. They concluded that public spending may be a significant determinant of growth in countries that can do productive things with it. $\mathrm{Wu}$ et al. (2010) examined the causal relationship between public spending and economic growth in 182 countries, from 1950 to 2004. The results of this study confirmed Wagner's law and the assumption that public spending is useful for economic growth; when countries are classified by income level and by corruption level, the causality runs in both directions, excepted the low-income countries. In these countries, public expenditures do not granger cause economic growth. Similarly, Akitoby et al. (2006) examined the short run and long run relationship between public spending and economic growth in 51 developing countries. They concluded that product and spending are cointegrated for most countries in the sample. This result confirms the law of Wagner.

\section{Public spending composition and economic growth in developing countries.}

Other studies tested the relationship between public spending composition and economic growth in developing countries. Amponsah (2009) examined the effects of disaggregate spending on economic growth in Ghana from 1970 to 2004. He found that public spending on health and infrastructure positively affect economic growth. The results also indicate that public spending on education do not have significant effect on economic growth in the short run. Dikeogu et al. (2016) analysed the impact of disaggregate public spending on economic growth in Nigeria from 1970 to 2013. They found that these spending have a significant impact on economic growth. Nurudeen and Usman (2010) analysed the effects of disaggregate government expenditures on economic growth in Nigeria from 1970 to 2008. The framework is this study was based upon Keynesian theory and endogenous growth theory. The results reported that total capital expenditures, total current expenditures and educational expenditures have a negative effect on economic growth. But, public spending on transport and communication, and public spending on health positively influence economic growth. Oyinlola and Akinnibosun (2013) used Gregory Hansen structural breaks cointegration technique to study the relationship between disaggregate public expenditures and economic growth in Nigeria from 1970 to 2009.Their results confirmed Wagner's law. Nworji et al. (2012) also studied the impact of the composition of public spending on economic growth in Nigeria from 1970 to 2009. They concluded that public expenditures have a significant and positive impact on economic growth. Ordinary spending on transfers and community and social services were also found to have positive impact on growth. Ighodaro and Oriakhi (2010) tested the validity of Wagner's law in Nigeria from 1961-2007. They examined the impact of economic growth on general administration expenditures and on social and community services expenditures. They found a long run relationship between the dependent variable and independent variables ; except where GDP is used as independent variable. Keynesian asumption was confirmed, while Wagner's law has been only partially confirmed. Olulu et al. (2014) studied the empirical relationship between health expenditures, educational expenditures and economic growth in Nigeria from 1980 to 2010. The results pointed to an inverse relationship between public spending on health and economic growth. The results also revealed a positive impact of educational expenditures on economic growth. Iheanacho (2016) examined the short run and long run relationship between public expenditures and economic growth in Nigeria from 1986 to 2014. He found a negative and significant relationship between economic growth and recurrent expenditures in the long run; and in the short run, he found a positive short run relationship between the variables. The study also highlighted a negative and significant long run effect of capital expenditure on economic growth. Olabisi and Funlayo (2012) studied the relationship between public spending composition and economic growth in Nigeria from 1960 to 2008. The result pointed out the positive impact of current expenditures on economic growth. Capital expenditures have non-significant impact on economic growth. They also found that public spending on education negatively influences economic growth, while government expenditures on health and agriculture have a positive 
impact on economic growth. Segun and Adelowokan (2015) examined the impact of public spending composition on economic growth in Nigeria from 1970 to 2008. Empirical results showed that current expenditures have a positive impact on economic growth. But capital expenditures have a non significant impact on economic growth. Ashwani and Sheera (2015) analyzed the impact of public spending components on economic growth in India. They found that capital expenditures and private capital formation expenditures have a positive and significant impact and economic growth. Saad and Kalakech (2009) investigated the effects of public sectoral spending on economic growth in Lebanon from 1962 à 2007. The study analyzed the effects of educational spending, health spending, agricultural expenditures, and military expenditures on economic growth. They concluded that educational expenditures have a positive impact on growth, both in short- and long-term. The results also reported that military and health expenditures negatively influence growth, in the long-term; and these expenditures have a non-significant impact on growth, in the short-term. Agricultural expenditures are non-significant, both in the short-and long-term. Jaroensathapornku (2010), in a study of the impact of public expenditures on economic growth in Thailand, found that public expenses on research and development positively influence economic growth, in the long run. On his part, Suanin (2015) examined, using different types of econometric techniques, the effects of different types of expenditure on economic growth in Thailand for the 1993-2014 period. He found that budgetary expenditures positively influence economic growth, in the long-term. The results also revealed that extra-budgetary expenditures and quasi-fiscal expenditures have a positive impact on economic growth, in the short-term. Mansouri (2008) analysed the impact of public spending composition on economic growth in Egypt, Morocco and Tunisia, in short-and long-term. He found that, in the 3 countries, government expenditures on investment have a positive impact on economic growth. He also found that current expenditures negatively influence economic growth in the 3 countries. Furthermore, Nubukpo (2003) assessed the impact of the composition of public spending on economic growth of West African Economic and Monetary Union countries from 1965 to 2000. He founded that public consumption expenditures have negative effect on growth at short and middle run, for those countries; but public investment expenditures have positive impact on economic growth of the countries. Togbenu (2017) studied the impact of public spending composition on economic growth in 20 developing countries over the 1985-2013 period. This study took into account the possibility of a non-linear relationship between the 2 variables. For this purpose, they applied the generalized moment method in a dynamic panel model. The results of this study pointed out the existence of a non linear relation between total public spending and economic growth. Gohsh and Gregoriou (2008) studied the impact of public spending on economic growth for a sample of 15 developing countries for 28 years. Their conclusion was that current expenditures have positive and significant effect on economic growth; but capital expenditures were found to have negative effect on growth. Bose et al. (2007) also examined the effects of government spending growth of 30 developing countries from 1970 to 1980.For them, the share of public capital expenditures in GDP is positively and significantly correlated with economic growth; but current expenditures are not significant. At the disaggregated level, government investment in education and total expenditures on education are the only spending that are significantly associated to growth, when budget constraint and omitted variables are taken into account. Gupta et al. (2005) assessed the effects of fiscal consolidation and spending composition on economic growth of 39 low income countries during the 1990s. They also found that public spending positively affect economic growth up to the limit of $30 \%$, and after this limit, it negatively affects growth. Their results revealed that countries where spending are focused on wages tend to grow in a slower way, whereas countries that allocate more important parts of capital and non-wage goods and services experiment a faster growth in production. Odedokun (2001) tested the impact of public spending on economic growth in 103 developing countries, over 3 decades. This study based on panel data, concluded that public spending effects on economic growth vary across groups of countries. Capital expenditures and current expenditures on goods and services have a negative impact on economic growth. He also found that salary expenditures positively influence growth.

These empirical studies have shown that the relationship between public spending and economic growth differs from one country or group of countries to another. It also depends on the level and composition of public spending.

\section{Conclusion}

The survey sets out the theoretical and empirical debate on relationship between public spending and economic growth. Many theories focused on the necessity of state intervention in the economy. They addressed indirectly the impact of public spending on economic growth. In fact, liberal theories promoted self-regulating mechanisms of markets and showed the conditions of state intervention in the economy. According to Keynes, 
unemployment is not only linked to labor market. It is linked to other markets and especially to finance. Keynes advocated state intervention via public expenditure. That intervention should take two dominant forms, namely the economic policies in favor of investment and income redistribution policies. Robert Barro showed the contribution of public spending to economic growth, with particular emphasis on public infrastructures. He argued that government spending on infrastructure investment improves private companies' productivity. Thus, it causes increasing return to scale, in the long run. Barro recommended therefore its funding through taxation. Nevertheless, it should be stressed that the evolution of public spending may depend on economic growth. Adolph Wagner showed that public expenditures increase more than proportionally in relation to economic growth. The empirical literature has already touched on the relationship between public spending level and economic growth. Empirical studies carried out on differents samples of developing countries have had mixed results. On the whole, these results argue neither in favor of Wagner's law, nor in favor of Keynesian hypothesis. In subsaharan Africa, literature hightlighted a positive and significant impact of total public expenditures on economic growth. In the specific case of west African economic and monetary union, studies revealed the existence of a long run relationship between dépenses public spending and economic growth. The literature also revealed that total public expenditures have a non significant impact on economic growth, in the short term. But, the impact differs from country to country, in the long term. In Nigeria, studies highlighted the existence of a long run relashionship between public spending and economic growth. Studies also revealed a mixed impact of agregate spending on economic growth. In India, studies have indicated that there is a long run relationship between public expenditures and economic growth. Most of studies in India argued in favor of a direction of causality from Gross Domestic Product to public expenditures. This result confirmed the law of Wagner for India. In Thailand, the literature indicated a long run relationship between public expenditures and economic growth; The literature in that country has also shown that government expenditures cause economic growth. In Turkey, results about causal relationship between public expenditures and economic growth are mixed. However, the impact of economic growth on government expenditures was found to be positive, conforming to Wagner's law. In recent years, there has been numerous empirical studies on the relationship between public spending level and economic growth. However, that literature has some shortcomings. In fact, a few empirical studies have been done in Thailand and Sub-Saharan Africa. Further research could revisit the relationship between public spending level and economic growth in Thailand and Sub-Saharan Africa. The empirical literature has also taken into account the relationship between the composition of public spending and economic growth. Most studies on groupings of developing are far from eliciting unanimity on the linearity of relationship between spending and growth. Results of studies on the relationship between capital spending and growth, as well as studies on the relationship between current spending and economic growth were discussed controversially. For some countries, at a disagregate level, only total government investment in education were significantly associated to economic growth, when budgetary constraint and omitted variables are taken into account. Concerning West African Economic and Monetary Union (WAEMU), literature revealed that consumption expenditures negatively affect economic growth, in the short and middle term. But, government investment expenditures have a positive impact on economic growth of WAEMU countries. Numerous studies have considered the relationship between public spending composition and economic growth in individual countries. In the case of Ghana, literature highlighted the positive impact of public spending on health and infrastructures on economic growth. Studies have also revealed that the impact of public spending on education on economic growth is not significant. A multitude of studies have examined the relationship between public spending composition and economic growth in Nigeria. These studies were done sometimes on the economic composition of public spending, sometimes on their functional composition. The empirical results are not very conclusive. In the case of India, capital expenditures and private capital formation have had a positive and significant impact on economic growth. In Lebanon, public expenditures on education have a positive impact on economic growth, in both short and long term. Literature also reported that military and health expenditures have a negative impact on economic growth, in the long term. But, they have a non significant impact on economic growth in the short term. Agriculture expenditures were found to be non significant, both in the short and long term. In the case of Thailand, literature highlighted the positive impact of public expenditures on research and development and budgetary expenditures on economic growth. But extra-budgetray and quasi-fical expenditures positively influence economic growth, in the short term. In the case of Egypte, Morocco and Tunisia, government investment expenditures have a positive impact on economic growth. But current expenditures have a positive impact on economic growth, in all three countries. The existing literature on the relationship between public expenditures composition and economic growth is subject to some deficiences. In fact, few studies have examined the relashionship between the two 
variables in the WAEMU area as a whole, in Ghana, India, Egypte, Morocco and Tunisia. Therefore, further empirical research could revisit this issue in these developing countries and regions.

\section{References}

1. Afonso, A., Furceri, D. (2010). Government size, composition, volatility and economic growth. European Journal of Political Economy, 26, 517-532.

2. Afonso, A., Schuknecht, L., Tanzi, V. (2005). Public sector efficiency: an international comparison. Public choice, 123, 321-347.

3. Agbonkhese, A.O., Asekome, M.O. (2014). Impact of public expenditure on the growth of Nigerian economy. European Scientific Journal, ESJ 10.

4. Ahmad, M. (2014). Government expenditure and economic growth: An econometric test for India. International Journal of Social Science and Humanities.

5. Akhabbar, A., Lallement, J. (2011). Applying general equilibrium theory: from Walras to Leontief.

6. Akitoby, B., Clements, B., Gupta, S., Inchauste, G. (2006). Public spending, voracity, and Wagner's law in developing countries. European Journal of Political Economy, 22, 908-924.

7. Aschauer, D.A. (1989). Is public expenditure productive? Journal of monetary economics 23, 177-200.

8. Ashwani, B., Sheera, V.P. (2017). Public spending and economic growth for Indian states. International Journal of Public Sector Performance Management 3, 250-265.

9. Bagdigen, M., Cetintas, H. (2004). Causality between public expenditure and economic growth: The Turkish case.

10. Barbiero, O., Cournède, B. (2013). New econometric estimates of long-term growth effects of different areas of public spending.

11. Barro, R.J. (1990). Government spending in a simple model of endogeneous growth. Journal of political economy 98, S103-S125.

12. Barro, R.J., Sala-i-Martin, X. (1992). Public finance in models of economic growth. The Review of Economic Studies, 59, 645-661.

13. Bayraktar, N., Moreno-Dodson, B. (2015). How can public spending help you grow? An empirical analysis for developing countries. Bulletin of Economic Research, 67, 30-64.

14. Bhatt, A., Sardoni, C. (2016). Public Expenditure and Growth: The Indian Case.

15. Bitone, A., Carzola, A., Dollo, C., Drai, A.-M. (2002). Etat. In: Dictionnaire des sciences économiques. Armand Colin.

16. Bleaney, M., Gemmell, N., Kneller, R. (2001). Testing the endogenous growth model: public expenditure, taxation, and growth over the long run. Canadian Journal of Economics/Revue canadienne d'économique 34, 3657.

17. Bose, N., Haque, M.E., Osborn, D.R. (2007). Public expenditure and economic growth: a disaggregated analysis for developing countries. The Manchester School 75, 533-556.

18. Carrère, C., De Melo, J. (2012). Fiscal spending and economic growth: some stylized facts. World Development 40, 1750-1761.

19. Cazzavillan, G. (1996). Public spending, endogenous growth, and endogenous fluctuations. Journal of Economic Theory 71, 394-415.

20. Chen, B.-L. (2006). Economic growth with an optimal public spending composition. Oxford Economic Papers $58,123-136$.

21. Corsetti, G., Roubini, N. (1996). Optimal government spending and taxation in endgenous growth models. National bureau of economic research.

22. Czernich, N., Falck, O., Kretschmer, T., Woessmann, L. (2011). Broadband infrastructure and economic growth. The Economic Journal 121, 505-532.

23. De La Croix, D., Michel, P. (2002). A theory of economic growth: dynamics and policy in overlapping generations. Cambridge University Press.

24. Delavallade, C. (2006). Corruption and distribution of public spending in developing countries. Journal of economics and finance, 30, 222-239.

25. Demurger, S. (2001). Infrastructure development and economic growth: an explanation for regional disparities in China? Journal of Comparative economics, 29, 95-117.

26. Devarajan, S., Swaroop, V. (1993). What do governments buy? The composition of public spending and economic performance.

27. Devarajan, S., Swaroop, V., Zou, H. (1996). The composition of public expenditure and economic growth. Journal of monetary economics, 37, 313-344. 
28. Dikeogu, C.C., Ohale, L., Otto, G. (2016). Public expenditure and economic growth in Nigeria. International Journal of Advanced Academic Research.

29. Esfahani, H.S., Ramírez, M.T. (2003). Institutions, infrastructure, and economic growth. Journal of development Economics, 70, 443-477.

30. Fan, S., Hazell, P.B., Thorat, S. (1998). Government spending, growth and poverty: An analysis of interlinkages in rural India. International Food Policy Research Institute (IFPRI).

31. Fan, S., Yu, B., Saurkar, A. (2008). Public spending in developing countries: trends, determination, and impact. Public expenditures, growth, and poverty, 20-55.

32. Fölster, S., Henrekson, M. (2001). Growth effects of government expenditure and taxation in rich countries. European Economic Review, 45, 1501-1520.

33. Gangal, V.L., Gupta, H., 2013. Public Expenditure and Economic Growth a case study of India. Global Journal of Management and Business Studies, 3, 191-196.

34. Ghosh, S., Gregoriou, A. (2008). The composition of government spending and growth: is current or capital spending better? Oxford Economic Papers, 60, 484-516.

35. Glomm, G., Ravikumar, B. (1997). Productive government expenditures and long-run growth. Journal of Economic Dynamics and Control, 21, 183-204.

36. Govindaraju, V.C., Rao, R., Anwar, S. (2011). Economic growth and government spending in Malaysia: a reexamination of Wagner and Keynesian views. Economic Change and Restructuring, 44, 203-219.

37. Gupta, S., Clements, B., Baldacci, E., Mulas-Granados, C. (2005). Fiscal policy, expenditure composition, and growth in low-income countries. Journal of International Money and Finance, 24, 441-463.

38. Hayek, F.A. (1944). The Road to Serfom. Dymock's Book Arcade.

39. Hayek, F. (1944). Scientism and the study of society. Part III. Economica 11, 27-39.

40. Herndon, T., Ash, M., Pollin, R. (2014). Does high public debt consistently stifle economic growth? A critique of Reinhart and Rogoff. Cambridge journal of economics, 38, 257-279.

41. Hsieh, E., Lai, K.S. (1994). Government spending and economic growth: the G-7 experience. 0003-6846 26, $535-542$.

42. Hulten, C.R. (1996). Infrastructure capital and economic growth: How well you use it may be more important than how much you have. National Bureau of Economic Research.

43. Ighodaro, C.A., Oriakhi, D.E. (2010). Does the relationship between government expenditure and economic growth follow Wagner's law in Nigeria. Annals of University of Petrosani Economics, 10, 185-198.

44. Theanacho, E. (2016). The Contribution of Government Expenditure on Economic Growth of Nigeria Disaggregated Approach. Int J Eco Manag Sci.

45. Jaroensathapornkul, J. (2010). Spending for growth: An empirical evidence of Thailand. Applied Economics Journal, 17, 27-44.

46. Jiranyakul, K., Brahmasrene, T. (2007). The relationship between government expenditures and economic growth in Thailand. Journal of Economics and Economic Education Research, 8, 93.

47. Judd, K.L. (1999). Optimal taxation and spending in general competitive growth models. Journal of Public Economics, 71, 1-26.

48. Korkmaz, S. (2013). Evaluating the relationship between public expenditures and economic growth for Turkey. Actual Problems of Economics, 382-391.

49. Kumar, S. (2009). Further evidence on public spending and economic growth in East Asian countries.

50. Künü, S. (2015). The Effects of Public Expenditures on Economic Growth: An Empirical Analysis for Turkey. International Journal of Business and Social Science, 6.

51. Maku, O.E. (2009). Does government spending spur economic growth in Nigeria?

52. Mansouri, B. (2008). Fiscal policy and economic growth: Egypt, Morocco and Tunisia compared, in: Proceeding in UNECA Conference on: Macroeconomic Policy, Productive Capacity and Economic Growth in Africa. Addis Ababa, 23-25.

53. Minea, A. (2008). The role of public spending in the growth theory evolution. Romanian Journal of Economic Forecasting 2, 99-120.

54. Mohtadi, H., Roe, T.L. (2003). Democracy, rent seeking, public spending and growth. Journal of Public Economics 87, 445-466.

55. Ng, Y.-K. (2000). The optimal size of public spending and the distortionary cost of taxation. National Tax Journal, 253-272.

56. Nketiah-Amponsah, E. (2009). Public spending and economic growth: evidence from Ghana (1970-2004).

Development Southern Africa, 26, 477-497. 
57. Nworji, I.D., Okwu, A.T., Obiwuru, T.C., Nworji, L.O. (2012). Effects of public expenditure on economic growth in Nigeria: A disaggregated time series analysis. International Journal of Management Sciences and Business Research, 1, 1-15.

58. Odedokun, M.O. (2001). Public finance and economic growth: Empirical evidence from developing countries. WIDER Discussion Papers//World Institute for Development Economics (UNU-WIDER).

59. Okoro, A.S., (2013). Government spending and economic growth in Nigeria (1980-2011). Global Journal of Management And Business Research.

60. Olabisi, A.S., Oloni, E.F. (2012). Composition of public expenditure and economic growth in Nigeria. Journal of Emerging Trends in Economics and Management Sciences, 3, 403.

61. Olulu, R.M., Erhieyovwe, E.K., Andrew, U. (2014). Government expenditures and economic growth: The Nigerian experience. Mediterranean Journal of social sciences, 5, 89.

62. Oyinlola, M.A., Akinnibosun, O. (2013). Public expenditure and economic growth nexus: Further evidence from Nigeria. Journal of Economics and International Finance, 5, 146.

63. Plümper, T., Martin, C.W. (2003). Democracy, government spending, and economic growth: A political-economic explanation of the Barro-effect. Public Choice 117, 27-50.

64. Rajkumar, A.S., Swaroop, V. (2008). Public spending and outcomes: Does governance matter? Journal of development economics, 86, 96-111.

65. Röller, L.-H., Waverman, L. (2001). Telecommunications infrastructure and economic development: A simultaneous approach. American economic review 909-923.

66. Saad, W., Kalakech, K. (2009). The nature of government expenditure and its impact on sustainable economic growth. Middle Eastern Finance and Economics, 1, 39-47.

67. Samuels, W.J., Biddle, J.E., Davis, J.B. (2008). A companion to the history of economic thought. John Wiley \& Sons.

68. Segun, O.M., Adelowokan, O.A. (2015). Measuring the Impact of Public Expenditure on Economic Growth in Nigeria. Journal of Social Science Studies 2, 46.

69. Siraj, T. (2012). Official development assistance (ODA), public spending and economic growth in Ethiopia. Journal of Economics and International Finance, 4, 173.

70. Smith, D.B. (2006). Living with Leviathan: public spending, taxes and economic performance.

71. Srinivasan, P. (2013). Causality between Public Expenditure and Economic Growth: The Indian Case. International Journal of Economics \& Management, 7.

72. Suanin, W. (2015). The impact of government expenditure on economic growth in Thailand. Presented at the International Conference on Trends in Economics, Humanities and Management, Singapore.

73. Sunday, O.A. (2013). Government spending and economic growth in Nigeria (1980-2011). Singaporean Journal of Business, Economics and Management Studies, 2, 81-92.

74. Tang, C.F. (2009). An examination of the government spending and economic growth nexus for Malaysia using the leveraged bootstrap simulation approach. Global Economic Review, 38, 215-227.

75. Turnovsky, S.J., Fisher, W.H. (1995). The composition of government expenditure and its consequences for macroeconomic performance. Journal of Economic Dynamics and Control, 19, 747-786.

76. Usman, A., Mobolaji, H.I., Kilishi, A.A., Yaru, M.A., Yakubu, T.A. (2011). Public expenditure and economic growth in Nigeria. Asian Economic and Financial Review 1, 104.

77. Vaggi, G., Groenewegen, P. (2016). A concise history of economic thought: From mercantilism to monetarism. Springer.

78. Van Dalen, H.P., Swank, O.H. (1996). Government spending cycles: Ideological or opportunistic? Public Choice, 89, 183-200.

79. Ventelou, B., Bry, X. (2006). The role of public spending in economic growth: Envelopment methods. Journal of Policy modeling, 28, 403-413.

80. Von Hayek, F.A. (1931). Prices and production.

81. Yasin, M. (2003). Public spending and economic growth: empirical investigation of Sub-Saharan Africa. Southwestern Economic Review, 30, 59-68.

82. Yilgör, M., Ertugrul, C., Celepcioglu, M. (2012). The effect of public expenditure on economic growth: Turkey example. Investment Management and Financial Innovations, 9, 193-202.

83. Zhang, T., Zou, H. (1998). Fiscal decentralization, public spending, and economic growth in China. Journal of public economics, 67, 221-240.

84. Zou, H. (1996). Taxes, federal grants, local public spending, and growth. Journal of Urban Economics, 39. 